\title{
Upgrading in the European Union
}

Citation for published version (APA):

de Grip, A., \& Hoevenberg, J. (1996). Upgrading in the European Union. Researchcentrum voor Onderwijs en Arbeidsmarkt, Faculteit der Economische Wetenschappen. ROA Research Memoranda No. 3E https://doi.org/10.26481/umaror.199603E

Document status and date:

Published: 01/01/1996

DOI:

10.26481/umaror.199603E

Document Version:

Publisher's PDF, also known as Version of record

\section{Please check the document version of this publication:}

- A submitted manuscript is the version of the article upon submission and before peer-review. There can be important differences between the submitted version and the official published version of record.

People interested in the research are advised to contact the author for the final version of the publication, or visit the DOI to the publisher's website.

- The final author version and the galley proof are versions of the publication after peer review.

- The final published version features the final layout of the paper including the volume, issue and page numbers.

Link to publication

\footnotetext{
General rights rights.

- You may freely distribute the URL identifying the publication in the public portal. please follow below link for the End User Agreement:

www.umlib.nl/taverne-license

Take down policy

If you believe that this document breaches copyright please contact us at:

repository@maastrichtuniversity.nl

providing details and we will investigate your claim.
}

Copyright and moral rights for the publications made accessible in the public portal are retained by the authors and/or other copyright owners and it is a condition of accessing publications that users recognise and abide by the legal requirements associated with these

- Users may download and print one copy of any publication from the public portal for the purpose of private study or research.

- You may not further distribute the material or use it for any profit-making activity or commercial gain

If the publication is distributed under the terms of Article $25 \mathrm{fa}$ of the Dutch Copyright Act, indicated by the "Taverne" license above, 


\section{Upgrading in the European Union}

Andries de Grip, Jeroen Hoevenberg

ROA-RM-1996/3E

Research Centre for Education and the Labour Market

Faculty of Economics and Business Administration

University of Limburg

Maastricht, April 1996 


\section{Contents}

Page

Abstract

1 Introduction

2 Human capital, technological change and internal competitiveness

3 The occupational and skill structure of employment 6

3.1 The occupational structure of employment

3.2 The skill structure of employment

4 Upgrading the skill level of employment 9

4.1 First indications of upgrading 9

4.2 Changes in the occupational structure of employment 11

4.3 Changes in the skill structure of employment 13

4.4 Shifts in the educational level 15

4.5 Convergence or divergence in skill levels 16

5 Upgrading by means of continuing vocational training 17

5.1 Participation in training $\quad 17$

5.2 Divergence or convergence in participation in training 19

6 Complementarity of educational and training policies 20

7 Conclusion $\quad 22$

$\begin{array}{ll}\text { References } & 23\end{array}$

$\begin{array}{lr}\text { Appendix A } & 27\end{array}$ 


\begin{abstract}
Human capital factor endowments have become one of the main determinants of international competitiveness. Both to catch up in the technological race and to increase the long-term flexibility of the workforce, industrialized countries require a highly skilled labour force. This paper analyzes the skills upgrading process in the European Union, as reflected in shifts in the occupational structure of employment and changes in the skill requirements in the various occupational fields. We distinguish between upgrading by recruitment policies and by training policies.
\end{abstract}

Labour Force Survey data shows an increase in skill levels and rather stable participation in continuing vocational education. The data also reveal diverging trends, in the period 19831991, between the various Member States of the European Union, both with regard to the skill level of the working population and the rate of participation in training activities. Estimation results show that, in general, intermediate skilled workers participate more in training activities than highly skilled workers. This suggests some substitutability between initial education (i.e. recruitment policies) and continuing training. However, if we correct for the occupational field in which workers are employed, recruitment policies and training policies appear to be complementary rather than substitutes. This means that within the various occupational fields, continuing training increases the skill gap between highly skilled and intermediately skilled workers. Moreover, both intermediate and highly skilled workers participate significantly more in continuing training than low skilled workers. This again indicates an increase in the skill gap in the labour force in the EU Member States, which means that continuing training fails to achieve the upgrading of low skilled workers which is required if the labour supply is to be adjusted to transfer human resources towards activities which match the EU's comparative advantages.

We would like to thank Ed Willems for his help in developing the (modified) binomial logit model, and also Lex Borghans and Rolf van der Velden, for their comments on an earlier version of this paper. 


\section{Introduction}

The European Commission's 'White Paper' signals great problems in maintaining and eventually expanding employment in the European Union (Commission of the European Communities, 1993). In 1993 the number of unemployed workers in the European Union rose to above 17 million. The 'White Paper' describes several causes for this high unemployment (cf. OECD, 1994 and ILO, 1995).

- Europe has not succeeded in obtaining a sufficiently solid position in the international labour order: the labour markets of the future have been neglected because the Member States of the European Union have emphasized the traditionally strong sectors too much.

- The relatively high costs of less skilled workers stimulated capital investments while restraining the creation of jobs in the service sector.

- Many newly industrialised countries (NICs) are in competition with the European Union Member States, but the European Union is not capable of competing with these countries on cost terms.

The 'White Paper' indicates that the European Union has to catch up in the technological race if it is to increase employment levels. Rapid technological change offers great opportunities for increasing employment in the European Union, as the diffusion of new technologies is crucial for the Union's international competitive position. However, this requires a highly skilled labour force that gives comparative advantages in the growth sectors of the world economy. This point had also been stressed in the public debate in the USA: 'Our trading partners have realized that their productivity will determine both their international power and standard of living. These countries have made substantial commitments to educate and train their workforces. America has, in many respects failed to do the same' (U.S. Department of Labor, 1989, p. 1).

Such a technological development requires that the labour force should become more flexible. This is not just a matter of short-term labour flexibility, which is facilitated by the growth of various forms of atypical employment relations such as part-time work, temporary contracts, etc. (see e.g. Treu, 1992, Delsen, 1995 and De Grip et al., 1995). Long-term flexibility is also crucial. Long-term flexibility refers to the ability of workers to adapt quickly to new technologies or production processes. The main source of this long-term increase in the flexibility of the labour force is continuing vocational training (see e.g., ILO, 1995).

This paper will analyze the skills upgrading process in the European Union, as reflected in the shifts in the occupational structure of employment and the skill requirements in the various occupational sectors in the Member States of the European Union in the period 1988-1991. Following Groot and De Grip (1991), we distinguish between upgrading by means of increased investments in initial education (recruitment policies) and investments in continuing vocational training (training policies). We will also examine whether there are 
convergencies or divergencies between the various EU Member States with regard to investments in human capital in initial education and continuing vocational training in particular occupational sectors. Finally, we will analyze whether initial education and continuing training are complements or substitutes. This analysis focuses particularly on the question of whether training activities decrease or increase the skill gap between lower, intermediate and highly skilled workers.

The analysis utilizes data from the EUROSTAT Labour Force Survey, with regard to the occupational and skill structure of employment. ${ }^{1}$ Due to incompatibility problems this occupational and educational data has thus far not been published. However, by using data at a high level of aggregation (1-digit occupational data based on the ISCO'68) it is possible to diminish this problem to a great extent. Only Italy and the new Member States of Austria, Finland and Sweden have had to be excluded from the study, because EUROSTAT does not yet contain the necessary data for these countries. Furthermore, the results for Luxembourg are not discussed in this paper, because of the very small numbers in many cells of the occupation by education matrices for this country, which means that the data often shows unrealistic relative employment shifts although the absolute shifts are rather small. Finally, it should be borne in mind that, because of definition problems, the occupational sector of 'administrative and managerial workers' shows great differences within certain countries in the period discussed and thus has to be interpreted with great care.

The paper is organized as follows: Section 2 describes, in theoretical terms, the relevance of human capital in relation to technological change. In this section we point out that a continuous process of upgrading of the labour force is a crucial factor if the European Union wants to maintain high technological capabilities. Section 3 describes the occupational and skill structure of employment in the various Member States of the European Union. Section 4 outlines the upgrading of the skill level of employment in the European Union. After presenting some descriptive data on the extent to which upgrading processes are manifest in the shifts in the occupational structure of employment and the skill structures of the various occupational sectors we give a more condensed view by means of a shift-share analysis which distinguishes between the two components of the upgrading of the working population: the occupational effect and the substitution processes within occupational sectors. This section concludes by examining whether there is convergence or divergence between the EU Member States as regards the skill structures of the occupational sectors which have been distinguished. Section 5 describes upgrading processes in so far as they take place by means of continuing vocational training ('training policy) and analyzes whether there is convergence or divergence in the training

1. The data is from a study by the Research Centre for Education and the Labour Market (ROA), commissioned by the Directorate-General for Employment, Industrial Relations and Social Affairs (DG V) of the European Commission. 
participation rates in the various occupational sectors between the EU Member States. Section 6 presents the estimation results of a (modified) binomial logit analysis to detect the relation between participation in continuing training and the level of education of the labour force. This analysis indicates whether investments in initial education and worker's training are complementary or substitutes. Finally, section 7 summarizes the main conclusions of the paper.

\section{Human capital, technological change and international competitiveness}

Early classical economists showed that, even where a country is less efficient in absolute terms than other countries, it will still be able to increase its well-being by specializing in those products in which the country is relatively most efficient (Chacholiades, 1978). Neoclassical economic trade theory formally explains a country's relative advantage by means of its factor endowments. Each country will export the products that make use of the country's most abundant production factor (Heckscher-Ohlin theorem). Free international trade between countries will then cause factor price equalisation (see e.g. Leamer, 1984; Ethier, 1988). This whole process, however, will be disturbed because of government intervention. Another problem is that the theorem assumes that all countries have equal technologies, which is certainly not the case, and that it underestimates the importance of differences in the quality of labour. ${ }^{2}$

When Leontief applied the Heckscher-Ohlin model to the United States, he came to the conclusion that it was not applicable, since the USA was relatively well endowed with capital but exported labour-intensive goods (Leontief, 1953). This 'Leontief paradox' led economists to place greater emphasis on the dynamics of the increasing returns which are strongly associated with production technology and innovation (Dosi et al., 1990). This neotechnology theory of international trade is based on technological capabilities and innovativeness. Technological capabilities refer to the skills and knowledge necessary to develop, produce and sell products and production processes. Innovativeness is the actual realisation of that capacity to generate and commercialize new and better products and production processes. In this theory technology is both an input, as it is used in production processes, and an output, as it can be the product of particular production processes. Technical change is the chronic disturber of the existing patterns of comparative advantage between countries, which means that there will always be absolute cost differences ('technology gaps') between countries because of differences in technological capabilities and innovativeness.

2. Leamer (1992) and Cörvers and De Grip (1995) attempt to introduce heterogeneous labour into a Heckscher-Ohlin framework, by splitting labour up into various occupational sectors and skill levels, respectively. 
According to Spenner (1985), technological developments, or the way management implements new technologies, can influence the required skill level of the labour force in three ways. First, there may be an upgrading of the skill level required from the labour force, due to the combined effect of competition in product markets and management policies aiming at achieving higher production quality in order to meet the higher quality demand by customers. As Groot (1991) argues, these two effects are strongly related. In this case technological development requires more skills, greater responsibility and greater flexibility to operate in a changing environment, and thus leads to an increased skill level (see e.g. Rumberger and Levin, 1989). Upgrading of the labour force can in general take place in two ways: by means of recruitment policies or training policies. In the first case more highly skilled people are recruited, in the latter case the current workforce is trained (see also Groot and De Grip, 1991). The second possible outcome is a downgrading of the skill level. This hypothesis is based on the assumption that technological developments make tasks simpler, and will lead to de-skilling of employment (see e.g. Braverman, 1974). The third possible outcome is mixed and offsetting movements, a combination of upgrading and downgrading effects. As Bartel and Lichtenberg (1987) point out, in the first stages of the introduction of a technological innovation there will be an upgrading in the workforce, while in the later stages of the production process life-cycle there will be a downgrading tendency. At the national level this could mean that the final outcome will show little net change in the skill requirements, as some occupations will upgrade and others will downgrade.

Porter (1990) states that in a competitive environment the ability to increase productivity is the main determinant of a nation's long-term standard of living. However, sustained growth in productivity requires that an economy should upgrade continually. For a country this also means a continuous change in the factors of production needed within the various industries. No nation can be competitive on all markets at every moment, as the available stock of human resources and other resources is limited. A country should therefore use its available resources in the most productive ways. As Porter puts it: Access to abundant factors is less important in many industries than the technology and skills to process them effectively. Porter also mentions some other reasons why factor endowments have become less important. First, he states that the major part of world trade takes place between countries with comparable factor endowments. Second, because of globalization, industries no longer depend on the factor availability of one country, but can make use of the factors of production available in many countries.

Porter developed the 'Diamond' metaphor to help explain which factors influence competitiveness. This diamond shows what Porter sees as the determinants of national competitive advantage. First, there are the factor conditions of production. Secondly, there are the demand conditions, i.e. the nature of domestic demand for the industry's products or services. Thirdly, the availability of related and supporting industries is very important. Fourth, the organization of the firm and domestic competitive conditions are important. As 
in the Heckscher-Ohlin theory, factor endowments are important for a country's competitive position, but they are not the only determinants.

Porter subdivides the labour force into a basic part, which refers to unskilled and semiskilled workers, and an advanced part, of highly-educated workers. The basic part is either passively inherited from the past or can easily be created by modest human capital investments, whereas the advanced part requires large and often long-term investments in human resources. These human resources can be split up into a general part and a specialised part. The former refers to the available pool of broadly-skilled personnel with tertiary level education, and the latter to the very highly skilled and specialized part of the labour force. The latter group is an important factor in the development of new technologies whereas the former group plays a very important role in the diffusion of technologies. On these points Porters' theory reflects the central message of human capital theory, that education is an investment that leads to a lasting increase in productive capabilities (See e.g. Becker (1964) and Schultz (1971)).

Since the European Union Member States have to face high labour costs, and assuming that the European Union wishes to maintain its international competitiveness by maintaining high technological standards and highly innovative industries, a continuous process of upgrading of the labour force in the European Union is required. Ryan (1991), however, has stressed the importance of an adequate supply of intermediate-skilled workers for the efficiency of the production process, in contrast to the more usual notion in human-capital theory that a higher skill level is always reflected in higher productivity. Against Ryan's view, Daly (1986), in an analysis of the international competitive position of economic sectors in the United Kingdom and the USA, finds that differences in the employment shares of more highly skilled workers have a significant effect on relative labour productivity, whereas a higher share of intermediate-skilled workers did not have the expected positive effect on the relative labour productivity of an economic sector.

The combination of human capital generated by both initial education and continuing training, on the one hand, and technological development on the other hand is of crucial importance for the competitive position of the European Union. Upgrading processes due to technological and organizational innovation or diffusion processes can be reflected in the employment structure in two ways. First, upgrading may be evident in shifts in the occupational structure of employment, with increased shares of total employment being found in the more highly skilled occupational categories. Second, the upgrading processes can be reflected in the skill structure of the workers in a particular occupation. Therefore we use the occupational structure of employment as the starting point for measuring the skill structure of employment. 


\section{The occupational and skill structure of employment}

\subsection{The occupational structure of employment}

Before interpreting the upgrading tendencies in the occupational and skill structure of employment, the existing occupational and skill structure of employment in the various European Union Member States must first be examined. Table 1 shows the occupational structure of employment in the European Union Member States. The table shows that there are great differences between countries in the share which each occupational sector has in the country's total employment. For professional workers, 1991 employment shares range from $9.7 \%$ in Portugal to $26.1 \%$ in Denmark. Belgium and the Netherlands also have a large proportion of their total employment in this sector, whereas in Greece and Spain the sector is of lesser importance.

The employment shares of managerial workers range from $0.4 \%$ in France to $5.4 \%$ in the United Kingdom. The employment share for this occupational sector in France is extremely low, especially compared to the percentages in Germany and the United Kingdom. This indicates that there may have been problems in defining the managerial workers in the various Member States. It can also be seen that Greece, Spain and Portugal also show relatively low employment shares for managerial workers, whereas Belgium, Denmark and the Netherlands show relatively high shares.

The range of employment shares for clerical workers in the various European Union Member States is considerably smaller than we saw above for the professionals. In general, employment shares differ little from the European average, ranging from $12 \%$ in Greece to $21 \%$ in the Federal Republic of Germany. Other countries with a relatively low employment share for clerical workers are Spain, Portugal, Ireland and Denmark.

Remarkably, France and the United Kingdom have employment shares for this occupational sector which lie above the European average.

The employment shares of sales workers in the various countries within the European Union differ very little from the European average. Greece, Spain, the Netherlands and the United Kingdom have the highest employment shares in this occupational sector whereas Denmark and France have the lowest. However, the range in the employment shares is rather small, from $8.3 \%$ in Denmark to $11.9 \%$ in Greece. This indicates a rather fixed employment share of sales workers in total employment.

The disparity between the highest and lowest employment share for service workers, however, is much greater, varying from $9.2 \%$ in Denmark to $14 \%$ in the United Kingdom. The employment share of service workers is also very high in France and Spain, whereas it is very low in the Federal Republic of Germany, Denmark and Greece. 
Table 1

Occupational employment by country in 1991

\begin{tabular}{|c|c|c|c|c|c|c|c|}
\hline & $\begin{array}{l}\text { Professional } \\
\text { workers } \\
\%\end{array}$ & $\begin{array}{l}\text { Managerial } \\
\text { workers } \\
\%\end{array}$ & $\begin{array}{c}\text { Clerical } \\
\text { workers } \\
\%\end{array}$ & $\begin{array}{l}\text { Sales } \\
\text { workers } \\
\%\end{array}$ & $\begin{array}{c}\text { Service } \\
\text { workers } \\
\%\end{array}$ & $\begin{array}{l}\text { Agricultural } \\
\text { workers } \\
\%\end{array}$ & $\begin{array}{c}\text { Production } \\
\text { workers } \\
\%\end{array}$ \\
\hline Belgium & 22.6 & 4.2 & 20.0 & 9.0 & 10.4 & 2.7 & 31.2 \\
\hline Germany & 18.3 & 3.5 & 21.0 & 9.4 & 9.7 & 3.5 & 34.7 \\
\hline Denmark & 26.1 & 4.7 & 16.1 & 8.3 & 9.2 & 4.2 & 31.5 \\
\hline Greece & 13.1 & 1.7 & 12.0 & 11.9 & 9.3 & 21.0 & 30.9 \\
\hline Spain & 11.4 & 1.9 & 13.3 & 11.3 & 13.7 & 10.4 & 38.0 \\
\hline France & 18.9 & 0.4 & 20.5 & 8.9 & 14.0 & 6.3 & 31.1 \\
\hline Ireland & 16.4 & 3.7 & 15.8 & 10.7 & 11.8 & 12.8 & 28.8 \\
\hline Luxembourg & 12.7 & 1.0 & 26.2 & 8.8 & 13.7 & 4.2 & 33.4 \\
\hline Netherlands & 24.2 & 4.7 & 18.8 & 11.1 & 12.5 & 4.4 & 24.4 \\
\hline Portugal & 9.7 & 2.0 & 13.8 & 10.0 & 12.6 & 15.4 & 36.6 \\
\hline United Kingdom & 18.4 & 5.4 & 19.6 & 11.3 & 14.0 & 2.0 & 29.3 \\
\hline European Union & 17.8 & 3.1 & 18.8 & 10.1 & 12.3 & 5.8 & 32.3 \\
\hline
\end{tabular}

Source: EUROSTATTROA

The employment share of agricultural workers ranges from $2 \%$ in the United Kingdom to $21 \%$ in Greece. The table shows that Portugal, Ireland and Spain also have very high employment shares for this occupational sector. On the other hand, in Belgium and the Federal Republic of Germany the employment shares of this occupational sector are remarkably low. Even more surprising is the position of Ireland, which shows a high employment share for agricultural workers.

The occupational sector of production workers is the most complex and difficult to interpret because about one third of total employment in Europe is employed in this occupational sector and the occupations within this sector are much more diverse than those in the other occupational sectors. The employment shares in the various EU countries range from $24.4 \%$ in the Netherlands to $38 \%$ in Spain. In Portugal this occupational sector also has a high employment share.

\subsection{The skill structure of employment}

Table 2 shows the employment shares of the intermediate skilled workers ${ }^{3}$ in the occupational sectors distinguished in the European Union Member States. In general about one out of three workers employed in the European Union has intermediate skills. However the differences between the Member States are very large, from $7.1 \%$ in Portugal to $55.9 \%$ in the Federal Republic of Germany. Other countries with relatively small employment

3. This category refers to the ISCED level 3. 
shares for intermediate skilled workers are Spain, the United Kingdom and Greece with $17.6 \%, 20 \%$ and $23.7 \%$ respectively. In Denmark and the Netherlands the intermediate skilled workers have relatively high employment shares, of $49.7 \%$ and $41.8 \%$ respectively.

Table 2

Employment shares of intermediate skilled workers by country and occupation in 1991

\begin{tabular}{|c|c|c|c|c|c|c|c|c|}
\hline & $\begin{array}{l}\text { Professional } \\
\text { workers } \\
\quad \%\end{array}$ & $\begin{array}{l}\text { Managerial } \\
\text { workers } \\
\%\end{array}$ & $\begin{array}{l}\text { Clerical } \\
\text { workers } \\
\%\end{array}$ & $\begin{array}{l}\text { Sales } \\
\text { workers } \\
\%\end{array}$ & $\begin{array}{c}\text { Service } \\
\text { workers } \\
\%\end{array}$ & $\begin{array}{c}\text { Agricultural } \\
\text { workers } \\
\%\end{array}$ & $\begin{array}{l}\text { Productior } \\
\text { workers } \\
\%\end{array}$ & $\begin{array}{l}\text { Total } \\
\%\end{array}$ \\
\hline Belgium & 18.8 & 35.3 & 48.2 & 36.5 & 29.0 & 19.5 & 25.1 & 30.0 \\
\hline Germany & 31.9 & 45.2 & 69.3 & 68.1 & 53.1 & 46.3 & 59.9 & 55.9 \\
\hline Denmark & 32.4 & 53.1 & 68.6 & 64.7 & 42.9 & 44.8 & 52.4 & 49.7 \\
\hline Greece & 10.1 & 29.1 & 61.7 & 40.1 & 24.7 & 5.3 & 20.3 & 23.7 \\
\hline $\begin{array}{l}\text { Spain } \\
\text { France* }\end{array}$ & 15.4 & 26.7 & 44.4 & 19.2 & 12.6 & 3.8 & 13.5 & 17.6 \\
\hline Ireland & 17.9 & 38.7 & 62.5 & 44.4 & 33.0 & 16.8 & 22.2 & 31.4 \\
\hline Luxembourg & 28.1 & - & 29.6 & 11.4 & 4.6 & - & 1.1 & 13.3 \\
\hline Netherlands & 34.6 & 41.9 & 52.5 & 44.9 & 43.0 & 41.6 & 38.7 & 41.8 \\
\hline Portugal & 14.0 & 12.4 & 23.6 & 8.8 & 3.1 & 0.6 & 2.4 & 7.1 \\
\hline United Kingdom & 17.8 & 23.8 & 18.9 & 17.4 & 16.4 & 17.2 & 24.2 & 20.0 \\
\hline European Union & 24.5 & 33.7 & 47.5 & 37.6 & 28.4 & 17.2 & 35.0 & 33.9 \\
\hline
\end{tabular}

Source: EUROSTAT\ROA

The differences between the employment shares of intermediate skilled workers in the various occupational sectors are also very large. Employment shares range from an average of $17.2 \%$ for intermediate skilled agricultural workers to $47.5 \%$ for intermediate skilled clerical workers. In general the picture within occupations is the same as for the total employment of intermediate skilled workers in the Member States, with relatively low employment shares of intermediate skilled workers in Portugal, Spain, the United Kingdom and Greece and relatively high employment shares in the Federal Republic of Germany, Denmark and the Netherlands.

Table 3 shows the average employment share of the highly skilled workers ${ }^{4}$ in the European Union is $17.1 \%$. The differences between countries (except for Portugal) are relatively small. However, the differences between occupational sectors are extremely large. While only $3.5 \%$ of agricultural workers are highly skilled, the figure in the occupational sector of professional workers is $60.6 \%$. Remarkably, the country with the highest percentage of highly skilled workers in the professional occupational sector is

4. This category refers to ISCED levels 5 to 7. 
Greece. Spain and Portugal also have high percentages of highly skilled workers in this occupational sector, whereas the Federal Republic of Germany and Denmark have relatively low percentages of highly skilled workers in this occupational sector.

Table 3

Employment shares of highly skilled workers by country and occupation in 1991

\begin{tabular}{|c|c|c|c|c|c|c|c|c|}
\hline & $\begin{array}{l}\text { Professional } \\
\text { workers } \\
\%\end{array}$ & $\begin{array}{l}\text { Managerial } \\
\text { workers } \\
\%\end{array}$ & $\begin{array}{l}\text { Clerical } \\
\text { workers } \\
\%\end{array}$ & $\begin{array}{l}\text { Sales } \\
\text { workers } \\
\%\end{array}$ & $\begin{array}{c}\text { Service } \\
\text { workers } \\
\%\end{array}$ & $\begin{array}{c}\text { Agricultur } \\
\text { workers } \\
\%\end{array}$ & $\begin{array}{l}\text { Production } \\
\text { workers } \\
\%\end{array}$ & $\begin{array}{l}\text { Total } \\
\%\end{array}$ \\
\hline Belgium & 75.0 & 38.3 & 20.9 & 19.2 & 4.6 & 3.5 & 3.3 & 26.0 \\
\hline Germany & 55.0 & 43.7 & 10.3 & 9.1 & 7.6 & 12.0 & 8.7 & 18.8 \\
\hline Denmark & 54.5 & 32.1 & 12.1 & 6.9 & 5.4 & 3.8 & 4.8 & 20.4 \\
\hline Greece & 83.0 & 45.5 & 23.4 & 10.7 & 6.9 & 0.8 & 6.2 & 18.5 \\
\hline $\begin{array}{l}\text { Spain } \\
\text { France* }\end{array}$ & 75.2 & 32.5 & 14.7 & 5.4 & 1.9 & 0.7 & 1.1 & 12.5 \\
\hline Ireland & 75.1 & 44.3 & 15.2 & 11.7 & 9.4 & 6.2 & 5.5 & 21.1 \\
\hline Luxembourg & 50.7 & 62.5 & 8.6 & 4.3 & - & - & - & 9.7 \\
\hline Netherlands & 59.3 & 44.1 & 15.1 & 8.5 & 3.6 & 2.4 & 2.5 & 21.3 \\
\hline Portugal & 66.7 & 22.7 & 3.7 & 2.1 & 0.5 & - & 0.3 & 7.8 \\
\hline United Kingdom & 57.4 & 29.6 & 6.3 & 8.2 & 4.3 & 3.6 & 3.3 & 16.0 \\
\hline European Union & 60.6 & 36.2 & 10.7 & 8.3 & 4.7 & 3.5 & 4.8 & 17.1 \\
\hline
\end{tabular}

Source: EUROSTAT\ROA

\section{Upgrading the skill level of employment}

\subsection{First indications of upgrading}

As human capital theory indicates, investment in the skill level of the working population is very important in the development of a lasting increase in a country's productive capabilities. Table 4 shows the upgrading of the skill level of the labour force in the European Union in the period 1988-1991, as reflected in the considerable increases in the employment shares of both intermediate and highly skilled workers. The employment share of intermediate skilled workers even increased by 6.4 percentage points. However, the table also indicates that the Federal Republic of Germany has been largely responsible for this large increase, since the employment share of intermediate skilled workers in this country increased by 11.6 percentage points. Remarkably, Denmark shows a very small decrease in the employment share of intermediate skilled workers. For the highly skilled workers it can be seen that most countries show a similar employment increase. Only the United Kingdom shows a slight decrease in the employment share of highly skilled workers. 
Table 4

Percentage point changes in the employment shares of intermediate and highly skilled workers, 1988-1991

\begin{tabular}{lcc}
\hline Country & $\begin{array}{l}\text { Intermediate } \\
\text { skilled } \\
\text { \%-points }\end{array}$ & $\begin{array}{l}\text { highly } \\
\text { skilled } \\
\text { \%-points }\end{array}$ \\
\hline Belgium & 3.5 & 2.6 \\
Federal Republic of Germany & 11.6 & 2.6 \\
Denmark & -0.1 & 1.3 \\
Greece & 4.5 & 1.1 \\
Spain & 3.3 & 1.5 \\
France* & & \\
Ireland & 0.1 & 2.6 \\
Luxembourg & -4.2 & 2.8 \\
Netherlands** & 2.4 & 1.5 \\
Portugal & 1.1 & -0.1 \\
United Kingdom & & 1.7 \\
European Union & 6.4 & \\
* no data available & & \\
** no data for 1988 & & \\
\hline
\end{tabular}

Source: EUROSTAT\ROA

The increase in the employment shares of intermediate and highly skilled workers is indeed a first indication of upgrading tendencies. However there are two possible causes for such an upgrading process. First, upgrading can be caused by shifts in the occupational structure of employment, which may reflect changes in factor demands caused by technological changes. Second, upgrading can reflect changes in the skill structure within occupational sectors. ${ }^{5}$

Section 4.2. will discuss the extent to which these upgrading tendencies are caused by changes in the structure of occupational employment, while section 4.3. shows how far they are attributable to increases in the skill levels within occupational sectors. In section 4.4. a shift-share analysis will be used to determine whether the principal cause for the increase in the educational level of employment lies in changes in the occupational structure of employment or in increasing skill requirements within occupational sectors. In Section 4.5., a divergence/convergence-analysis is used to see whether the differences in skill levels by occupational sectors between the various Member States have increased or decreased.

5. Strictly speaking, it is uncertain whether this increase reflects increased skill requirements (demand-pull) or crowding out effects (supply-push) due to the increased skill level of the labour supply (see Teulings and Koopmanschap (1989)). 


\subsection{Changes in the occupational structure of employment}

\section{Winners on the European labour market}

Table 5 shows how the changes in the occupational structure of employment in the various Member States of the European Community have contributed to the increasing skill level. From the table, two principal occupational winners can be distinguished: professional workers and clerical workers. Portugal has the greatest increase in the percentage share of professional workers, by 2.1 percentage points. This indicates that the occupational structure of employment in Portugal is catching up in this respect. This cannot be said for Greece, where professional workers have a very low share of total employment and the increase in this share is well below the European average. Ireland, the Netherlands and France also show relatively low increases in the employment share of this occupational sector.

The differences in the shifts in the employment shares of clerical workers for the various EU countries are much greater. Changes range from a fall of 0.6 percentage points in Denmark to an increase of 1.7 percentage points in Spain. The decreases in Denmark and Ireland are very surprising as these are the only countries in which the employment share for this sector has decreased. If we look at countries in which this sector is of increasing importance, Greece, Spain and Portugal seem to be catching up with the other European countries.

\section{Losers on the European labour market}

In the period 1988-1991 there were two occupational losers on the European labour market: agricultural workers and production workers. The occupational employment shares of these two occupational sectors show an average decrease of 1.2 percentage points and 0.7 percentage points respectively.

For agricultural workers the differences between the various EU countries are very great. From the table it can also be seen that in Greece, Spain and Portugal, in particular, agricultural workers' shares in total employment decreased very rapidly. This is not surprising as these three countries are characterized by employment shares for this occupational sector which are far above the European average.

The other losing occupation, production workers, has a slightly different profile than the preceding occupational sector. Most remarkable is that employment shares in Greece, Spain and Ireland are increasing. This probably reflects a comparative cost advantage and high factor endowments of 'blue collar' workers in these countries. However, in Portugal, a country for which the same process might be expected, the employment share in this sector decreased. Also the position of the Netherlands is rather remarkable. The 
Netherlands has the lowest employment share in this occupational sector and the highest decrease in the share of all the EU countries. This might indicate that in this country technically-skilled production workers are becoming relatively scarce.

\section{Stable occupations}

Changes in the employment shares of the remaining occupational sectors, measured across the EU as a whole, are negligible. However, this does not mean that the differences between countries are by definition smaller. What we see is that the employment shifts in these occupational sectors in the various Member States largely cancel each other out, resulting in a stable occupational share at the European level.

Table 5

Percentage point changes in occupational employment by country, 1988-1991

\begin{tabular}{|c|c|c|c|c|c|c|c|}
\hline & $\begin{array}{l}\text { Professional } \\
\text { workers } \\
\text { \%-points } \\
\text {-points }\end{array}$ & $\begin{array}{l}\text { Managerial } \\
\text { workers } \\
\% \text {-points }\end{array}$ & $\begin{array}{l}\text { Clerical } \\
\text { workers } \\
\% \text {-points }\end{array}$ & $\begin{array}{l}\text { Sales } \\
\text { workers } \\
\% \text {-points }\end{array}$ & $\begin{array}{l}\text { Service } \\
\text { workers } \\
\% \text {-points }\end{array}$ & $\begin{array}{l}\text { Agricultural } \\
\text { workers } \\
\% \text {-points }\end{array}$ & $\begin{array}{l}\text { Production } \\
\text { workers } \\
\%\end{array}$ \\
\hline Belgium & 1.5 & 0.5 & 0.7 & -0.3 & 0.6 & -0.5 & -2.4 \\
\hline Germany & 1.1 & 0.2 & 0.7 & 0.0 & 0.5 & -0.8 & -1.7 \\
\hline Denmark & 0.7 & 0.7 & -0.6 & 0.2 & -0.6 & -0.1 & -0.3 \\
\hline Greece & 0.5 & -0.3 & 1.6 & 1.5 & -0.1 & -4.0 & 0.8 \\
\hline Spain & 1.5 & 0.1 & 1.7 & 0.1 & -0.2 & -3.3 & 0.1 \\
\hline France & 0.5 & -0.1 & 0.4 & 0.4 & 0.0 & -1.1 & -0.0 \\
\hline Ireland & 0.3 & 0.6 & -0.2 & -0.5 & 0.7 & -1.6 & 0.8 \\
\hline Luxembourg & 0.1 & -0.3 & 1.0 & 0.7 & -0.5 & 0.3 & -1.4 \\
\hline Netherlands & 0.4 & 0.9 & 0.4 & -0.4 & 0.4 & -0.5 & -1.2 \\
\hline Portugal & 2.1 & 0.5 & 1.2 & 0.9 & 0.5 & -3.9 & -1.4 \\
\hline United Kingdom & 1.9 & -1.6 & 0.8 & 0.0 & 0.6 & -0.5 & -1.2 \\
\hline European Union & 1.1 & -0.3 & 0.7 & 0.1 & 0.3 & -1.2 & -0.7 \\
\hline
\end{tabular}

Source: EUROSTATIROA

For managerial workers, the Netherlands and the United Kingdom show the most remarkable employment growth rates. The Netherlands has the highest increase in the employment share of managerial workers, even though the occupational employment share of managerial workers was already very high. The United Kingdom has the greatest employment share in this occupational sector, but also shows the greatest decrease in employment. Remarkably, the country with the highest employment share for sales workers, Greece, also has the greatest increase in their employment share. Denmark shows the largest decrease in the employment share of service workers, although its rate was already the lowest. The largest increase in the employment share of service workers can be found in Ireland, with 0.7 percentage points. 


\subsection{Changes in the skill structure of employment}

The second indicator for upgrading tendencies is the change in the skill structure of employment. ${ }^{6}$ Table 6 shows that all occupational sectors show a large increase in the employment share of intermediate skilled workers, especially in the occupational sectors of clerical, service and production workers. Remarkably, it is the occupational sectors of professional and managerial workers which show the smallest increase in the employment shares of intermediate skilled workers. The table also indicates that the differences between countries for the various occupational sectors, and also between occupational sectors within a country, are rather large. In Denmark the employment share of those with intermediate skills increased only in the service and agricultural sectors, whereas in the Federal Republic of Germany, Portugal and the United Kingdom the employment share of intermediate skilled workers increased in all occupational sectors. Some opposing trends can be observed within most occupational sectors. Only the occupational sector of agricultural workers shows an increase in the employment share of intermediate skilled workers for all countries.

Table 7 shows the changes in the employment shares of highly skilled workers in the European Community. The overall decrease in the employment share of highly skilled professional workers is striking. In Table 3 we saw that the highly skilled workers had an employment share in this occupational sector of more than $60 \%$. A decrease in the employment share of highly skilled workers means a great loss of employment in this occupational sector, especially as this occupational sector showed the highest growth rates for the period 1988-1991 (see Hoevenberg and De Grip, 1994). This means that intermediate skilled workers must have benefited most from the employment growth in this occupational sector, as it was the only skill level for which the employment share in this occupational sector increased. On balance this indicates a downgrading tendency in the level of employment. This indicates that as the occupational sector of professional workers starts to develop it offers highly skilled employment, and as the sector expands the percentage of less skilled employment starts to rise. According to Bartel and Lichtenberg (1987) this could indicate learning processes with respect to the use of new technologies. However, Belgium seems to be the exception to this rule, because Belgium has both a high skill level and a high employment share in this occupational sector.

Table 6

Percentage point changes in the employment share of intermediate skilled workers, 1988-1991

Professional Managerial Clerical Sales Service Agricultural Production

6. As there was no data available for the Netherlands for 1988 and 1989 , this country had to be excluded from this analysis. 
workers workers workers workers workers workers workers

\%-points \%-points \%-points \%-points \%-points \%-points \%points

\begin{tabular}{|c|c|c|c|c|c|c|c|}
\hline Belgium & -0.2 & 0.4 & 2.4 & 5.3 & 6.2 & 1.9 & 5.9 \\
\hline Germany & 1.3 & 8.8 & 12.9 & 13.9 & 14.3 & 17.4 & 14.6 \\
\hline Denmark & -0.4 & -2.5 & -1.8 & -0.2 & 6.8 & 9.3 & -1.7 \\
\hline Greece & 1.6 & -2.8 & -1.1 & 4.6 & 5.6 & 2.0 & 5.1 \\
\hline $\begin{array}{l}\text { Spain } \\
\text { France* }\end{array}$ & 2.5 & -1.4 & 4.6 & 1.7 & 2.4 & 0.1 & 2.9 \\
\hline Ireland & -1.7 & -3.3 & -1.1 & -0.1 & -1.8 & 2.7 & 1.9 \\
\hline $\begin{array}{l}\text { Luxembourg } \\
\text { Netherlands* }\end{array}$ & -16.1 & -7.5 & -6.6 & -4.8 & - & - & - \\
\hline Portugal & 2.7 & 0.9 & 5.6 & 2.6 & 1.1 & 0.2 & 1.0 \\
\hline United Kingdom & 0.6 & 0.2 & 1.5 & 0.1 & 2.7 & 1.9 & 2.0 \\
\hline E.U. & 2.3 & 4.6 & 7.6 & 6.3 & 7.7 & 6.3 & 7.2 \\
\hline
\end{tabular}

Source: EUROSTAT\ROA

Table 7

Percentage point changes in the employment share of highly skilled workers, 1988-1991

\begin{tabular}{|c|c|c|c|c|c|c|c|}
\hline & $\begin{array}{l}\text { Professional } \\
\text { workers } \\
\% \text {-points }\end{array}$ & $\begin{array}{l}\text { Managerial } \\
\text { workers } \\
\text { \%-points }\end{array}$ & $\begin{array}{l}\text { Clerical } \\
\text { workers } \\
\% \text {-points }\end{array}$ & $\begin{array}{l}\text { Sales } \\
\text { workers } \\
\% \text {-points }\end{array}$ & $\begin{array}{l}\text { Service } \\
\text { workers } \\
\text { \%-points }\end{array}$ & $\begin{array}{l}\text { Agricultural } \\
\text { workers } \\
\text { \%-points }\end{array}$ & $\begin{array}{l}\text { Production } \\
\text { workers } \\
\text { \%-points }\end{array}$ \\
\hline Belgium & 1.2 & -1.5 & 1.1 & 4.4 & 0.7 & - & 1.0 \\
\hline Germany & 0.7 & 6.5 & 2.5 & 0.8 & 1.3 & 4.9 & 1.6 \\
\hline Denmark & 3.3 & -0.5 & 0.9 & 0.7 & -1.9 & 0.5 & 0.0 \\
\hline Greece & -2.4 & 0.8 & -1.6 & 1.1 & 0.3 & 0.3 & 1.7 \\
\hline $\begin{array}{l}\text { Spain } \\
\text { France* }^{*}\end{array}$ & -2.1 & -0.6 & 1.7 & 1.3 & 0.1 & 0.1 & 0.0 \\
\hline Ireland & 2.7 & 4.7 & 3.5 & 2.9 & 2.7 & 1.6 & 1.2 \\
\hline $\begin{array}{l}\text { Luxembourg } \\
\text { Netherlands* }\end{array}$ & 15.1 & - & 3.5 & 1.5 & 0.1 & - & -1.6 \\
\hline Portugal & -2.7 & 4.6 & -0.3 & -0.1 & 0.0 & - & 0.0 \\
\hline United Kingdom & -3.8 & 0.3 & 0.6 & -1.1 & 0.0 & -1.0 & 0.4 \\
\hline E.C. & -1.2 & 3.6 & 2.0 & 0.4 & 0.3 & 1.1 & 0.7 \\
\hline
\end{tabular}

Source: EUROSTAT\ROA

\subsection{Shifts in the educational level}


A shift-share analysis enables us to indicate the extent to which the increase in the skill level of the labour force has been caused by changes in the occupational structure and to what extent it is caused by an increase in the educational level within the occupational sectors. The results of shifts in the occupational structure for the average educational level can be seen as the occupational effect, ${ }^{7}$ while the results caused by changes in the average educational level within an occupational sector can be seen as the substitution effect.

The occupation effect (OCC) for the period 1988-1991 can be computed as follows:

OCC $=\sum_{j=1}^{n}\left(e_{j 91}-e_{j 88}\right) * A E L_{j 88}$

In which:

$\mathrm{e}_{\mathrm{j}} \quad=$ share of occupational sector $j$ in total employment;

$\mathrm{AEL}_{\mathrm{j} 88}=$ average educational level in occupational sector $j$ in 1988.

The substitution effect (SUBST) than can be described as:

SUBST $=\sum_{j=1}^{n} e_{j 88} *\left(A E L_{j 91}-A E L_{j 88}\right)$

In addition to these two effects, there is an interaction effect (INTER):

INTER $=\sum_{j=1}^{n}\left(e_{j 91}-e_{j 88}\right) *\left(A E L_{j 91}-A E L_{j 88}\right)$

Table 8 shows the results of this shift-share analysis with regard to the components of the upgrading process of the labour force in the European Union Member States. In all countries the increase in the average educational level can to a large extent be attributed to the substitution effect. Only Portugal shows an occupational effect which is greater than the substitution effect. Greece and Spain also show a large occupational effect. The occupational effect probably reflects the catching-up process with regard to the industrial structure in these countries. The greater part of the upgrading process refers to the increased skill requirements in the various occupational sectors. This means that the upgrading process of the labour force is not caused by shifts in the industrial and occupational structure of employment, except in the three 'new' Southern Member States of the European Union: Portugal, Spain and Greece.

Table 8

7. This effect includes both the shifts in the employment structure by economic sector and the shifts in the occupational structure of employment within the various sectors of industry. 
Changes in the average educational level broken down into occupational, substitution and interaction effects.

\begin{tabular}{llll}
\hline Country & $\begin{array}{l}\text { Occupational } \\
\text { effect }\end{array}$ & $\begin{array}{l}\text { Substitution } \\
\text { effect }\end{array}$ & $\begin{array}{l}\text { Interaction } \\
\text { effect }\end{array}$ \\
\hline Belgium & & & -0.03 \\
Federal Republic of Germany & 0.37 & 0.92 & -0.02 \\
Denmark & 0.13 & 1.83 & 0.00 \\
Greece & 0.09 & 0.34 & -0.01 \\
Spain & 0.57 & 0.91 & 0.01 \\
France & 0.59 & 0.80 & -0.01 \\
Ireland & 0.14 & 0.90 & \\
Luxembourg & & & 0.03 \\
Netherlands & & 0.53 & -0.01 \\
Portugal & 0.68 & 0.18 & \\
United Kingdom & 0.12 & & \\
* no (adequate) data available & & & \\
& & &
\end{tabular}

Source: ROA

\subsection{Convergence or divergence in skill levels}

Graph 1 shows the results of the divergence/convergence analysis with regard to the average skill level by occupational sector between the various Member States of the European Union. This divergence/convergence analysis is based on the following formula:

$$
C l_{j}=\frac{\sum_{i=1}^{n}\left(X_{i j}-\overline{X_{j}}\right)^{2}}{(N-1)}
$$

where:

$\mathrm{Cl} \quad=$ Convergence (or Divergence) Indicator

$\mathrm{X}=$ Average skill level within the occupational sector

$\mathrm{j} \quad$ = Occupation

$\mathrm{i} \quad=$ Country

Figure 1 shows that there is a slight divergent tendency in the average educational levels for all occupational sectors, and that all occupational sectors show increasing indicator values. The differences in the indicator values between the various occupational sectors are interesting. The figure shows that the occupational sectors with the highest skill levels (professional workers, managerial workers and service workers) show the largest indicator value, i.e. the largest differences between the various countries, whereas the occupational sectors with the lowest skill levels (agricultural workers, production workers and service workers) show the lowest indicator values. This means that it is particularly with regard to 
the more skilled professions that the Member States differ in their competitive positions. The difference, as can be seen, is not decreasing, but rather slightly increasing.

Figure 1

Convergence in skill levels by occupational sectors

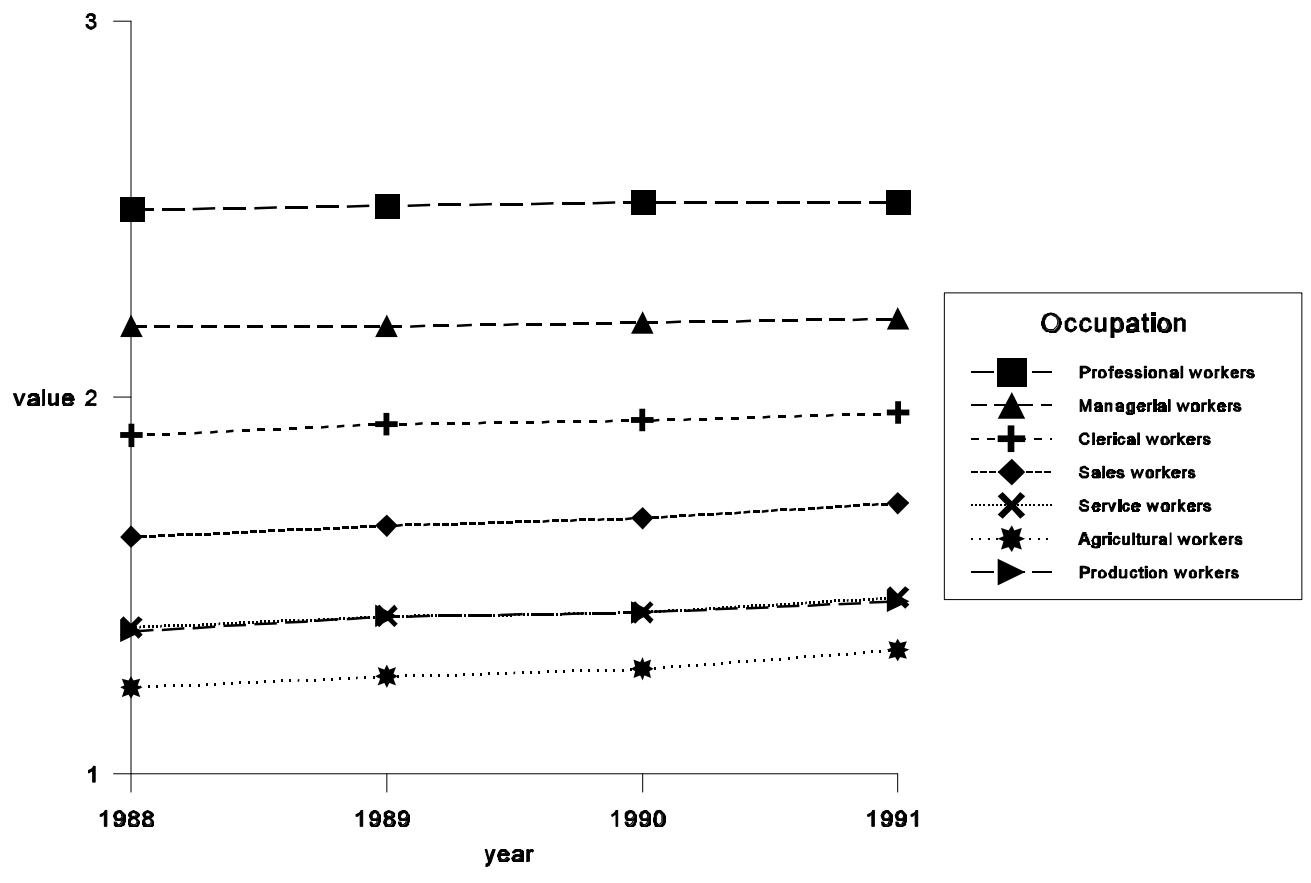

Source: ROA

\section{Upgrading by means of continuing vocational training}

\subsection{Participation in training}

Participation in training is a good indication of the upgrading of employment by means of training policies ${ }^{8}$ intended to increase the level of initial education in the labour force. Such training policies may be alternatives to recruitment policies. From Table 9 it can be seen that especially in Denmark, the Netherlands and the United Kingdom, participation in training is very important for maintaining or upgrading the skill level of the labour force. ${ }^{9}$

8. Participation in training refers to all kinds of training related to economic activity. This means that attending a school which provides training in specific subjects, in-company training, 'dual' training forms (a combination of vocational education and in-plant training) and apprenticeships are included. This can lead to double counting, where some training which leads to a formal qualification is measured once as increasing the educational level of the workers, and again as participation in training.

9. It should be noted that it is very difficult to compare the training data of the various Member States. However, we can assume that, within a country, the differences between occupational sectors can be interpreted without too many reservations. 
Bearing in mind the lower skill level of employment in the United Kingdom, as shown in the preceding section, training policies in this country would be expected to be very important for achieving the required upgrading of the skill level of the labour force. In that case a lower educational level is compensated for by more intensive participation in training. For the Netherlands and Denmark, however, both training policies and recruitment policies appear to be very important. These two countries combine a relatively highly skilled labour force with a high rate of participation in training activities. For the other Member States the recruitment of more highly skilled workers is probably more important than training policies. All these countries show training participation rates which are below the average European Union percentage.

Professional workers have the highest training participation rates, as can be seen from the table. In 1991, 14.2\% of all professional workers in Europe participated in training. In this occupational sector the United Kingdom leads the ranking with a training participation rate of $26.6 \%$. All countries of the European Union show a relatively high rate of participation in training for this occupational sector, compared to their average participation rates. In accordance with the general picture, Denmark, the Netherlands and the United Kingdom show the highest training participation rates, while the other Member States have much lower participation rates. Only the Federal Republic of Germany shows a participation rate close to the European average. This general pattern also applies to the other occupational sectors. There are however large differences between the various occupational sectors.

Table 9

Participation in training in the European Union in 1991

\begin{tabular}{|c|c|c|c|c|c|c|c|c|}
\hline & $\begin{array}{l}\text { Professional } \\
\text { workers } \\
\%\end{array}$ & $\begin{array}{l}\text { Managerial } \\
\text { workers } \\
\%\end{array}$ & $\begin{array}{l}\text { Clerical } \\
\text { workers } \\
\%\end{array}$ & $\begin{array}{l}\text { Sales } \\
\text { workers } \\
\%\end{array}$ & $\begin{array}{l}\text { Service } \\
\text { workers } \\
\%\end{array}$ & $\begin{array}{l}\text { Agricultural } \\
\text { workers } \\
\%\end{array}$ & $\begin{array}{l}\text { Productio } \\
\text { workers } \\
\%\end{array}$ & $\begin{array}{l}\text { Total } \\
\%\end{array}$ \\
\hline Belgium & 3.7 & 1.9 & 2.4 & 2.4 & 1.7 & 1.1 & 1.8 & 2.4 \\
\hline Germany & 10.5 & 4.9 & 9.1 & 9.2 & 9.2 & 6.3 & 8.7 & 9.0 \\
\hline Denmark & 23.3 & 17.4 & 25.1 & 31.9 & 25.4 & 16.8 & 19.4 & 22.7 \\
\hline Greece & 2.9 & 2.2 & 2.8 & 1.1 & 1.1 & 0.1 & 0.9 & 1.3 \\
\hline Spain & 6.5 & 1.9 & 6.9 & 2.0 & 2.9 & 0.7 & 1.5 & 3.0 \\
\hline France & 7.9 & 2.4 & 4.3 & 2.8 & 4.2 & 1.3 & 3.1 & 4.2 \\
\hline Ireland & 12.9 & 5.8 & 8.6 & 6.1 & 7.8 & 2.1 & 6.0 & 7.2 \\
\hline Luxembourg & 5.9 & - & 5.7 & 5.0 & 3.7 & 4.5 & 3.6 & 4.6 \\
\hline Netherlands & 23.1 & 13.9 & 25.5 & 24.0 & 22.6 & 14.0 & 16.6 & 21.2 \\
\hline Portugal & 8.2 & 1.3 & 7.5 & 3.1 & 3.1 & 1.0 & 2.3 & 3.6 \\
\hline United Kingdom & 26.6 & 14.8 & 17.2 & 17.9 & 14.1 & 9.8 & 10.2 & 16.3 \\
\hline European Union & 14.2 & 9.4 & 10.5 & 9.8 & 8.8 & 3.3 & 6.7 & 9.2 \\
\hline
\end{tabular}

Source: EUROSTAT\ROA 
As noted, professional workers participate most in training, whereas agricultural workers hardly participate in training at all. Participation in training is also very low for production workers. The other occupational sectors show percentages slightly above the total European average.

\subsection{Divergence or convergence in participation in training}

Again a convergence/divergence analysis was performed, to see whether the differences between the Member States are becoming larger or smaller. The formula used is very much the same as that given in Section 4.5:

$C l_{j}=\frac{\sum_{i=1}^{n}\left(Y_{i j}-\overline{Y_{j}}\right)^{2}}{(N-1)}$

where:

$\mathrm{Cl}=$ Convergence (or Divergence) Indicator

$\mathrm{Y}=$ Share of workers participating in training in occupational sector

j = Occupation

$\mathrm{i}=$ Country

Figure 2

Convergence in participation in training by occupational sector

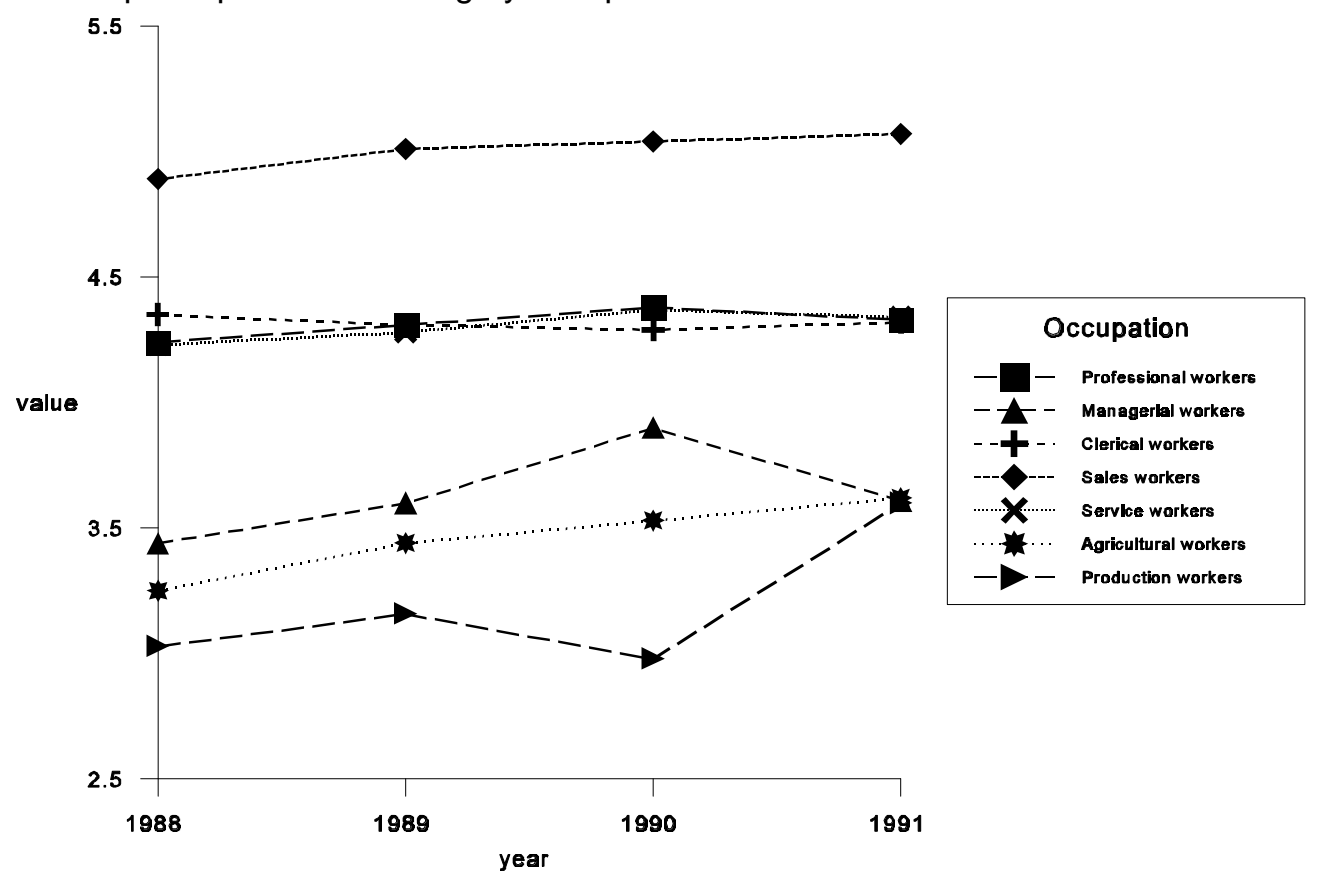

Source: ROA

Figure 2 shows the outcomes of the divergence/convergence analysis with regard to participation in training in the various occupational sectors. Here too, most occupational 
sectors show tendencies to diverge. Only the occupational sector of clerical workers shows a small converging trend. What is most remarkable in this figure is the strong diverging trend in the occupational sector of production workers, although the difference in training participation rates in this occupational sector is still among the lowest. Remarkably, the occupational sector of sales workers shows the largest differences in participation in training between Member States. Other occupational sectors with relatively large differences between the European Union Member States are those of clerical workers, professional workers and service workers.

\section{Complementarity of educational and training policies}

As mentioned, the labour force can be upgraded by recruiting more highly skilled workers or by continuing training. This section will analyze the relation between participation in continuing training and the level of education of the labour force. The analysis will seek particularly to ascertain whether initial education (i.e. recruitment policies) and participation in training are substitutes or complementary factors of production, using a (modified) binomial logit analysis of this relationship. ${ }^{10}$ The analysis distinguishes between three skill categories: low skilled, intermediate skilled and highly skilled workers, with the low skilled being used as the reference category. If initial education and investments in continuing training are substitutes, the intermediate skilled workers should have a higher rate of participation in training than the highly skilled workers.

A first analysis was done, taking only country effects into account. The first column of Table 10 shows that both intermediate skilled and highly skilled workers participate significantly more in training activities than low skilled workers. According to this analysis, the intermediate skilled workers seem to participate more in training activities than the highly skilled. This would indicate that initial education and participation in training are substitutes, at least for intermediate and highly skilled workers, since participation in training activities seems to decrease as the skill level rises. The first estimation results also confirm that participation in training is very important in Denmark and the Netherlands, and most important in the United Kingdom, as was already shown in section 5.1.

However, in a second analysis we corrected for the occupational sectors in which workers are employed. Remarkably, we now see that, in a given occupational field, the highly skilled workers participate more in training than the intermediate skilled, relative to the reference group of low skilled workers. The higher value of the parameter for participation in training of intermediate skilled workers in the first analysis is because intermediate skilled workers have relatively high employment shares in the occupational sectors in which participation in training activities is relatively high: clerical workers, sales workers and production workers.

10. The model is described in Appendix A. 
In the occupational sectors in which highly skilled workers have high employment shares professional workers and managerial workers - the rates of participation in training are the lowest.

Table 10

Relation between participation in training and level of education in the European Union in 1991

\begin{tabular}{|c|c|c|c|c|}
\hline Variable & & & Anal & \\
\hline $\begin{array}{l}\text { Constant } \\
\text { Belgium } \\
\text { Germany* }\end{array}$ & $\begin{array}{l}-4.09 \\
-0.90\end{array}$ & $\begin{array}{r}(-11.94) \\
(-3.24)\end{array}$ & $\begin{array}{l}-3.70 \\
-1.14\end{array}$ & $\begin{array}{l}(-7.92) \\
(-4.82)\end{array}$ \\
\hline $\begin{array}{l}\text { Denmark } \\
\text { Greece } \\
\text { Spain } \\
\text { Ireland } \\
\text { Netherlands } \\
\text { Portugal } \\
\text { United Kingdom } \\
\text { Professional workers } \\
\text { Managerial workers } \\
\text { Clerical workers* }\end{array}$ & $\begin{array}{r}1.30 \\
-1.40 \\
-0.33 \\
0.20 \\
1.32 \\
0.21 \\
1.64\end{array}$ & $\begin{array}{r}(5.31) \\
(-4.97) \\
(-1.08) \\
(0.76) \\
(5.26) \\
(0.60) \\
(5.40)\end{array}$ & $\begin{array}{r}1.34 \\
-1.66 \\
-0.55 \\
0.01 \\
1.26 \\
-0.02 \\
1.47 \\
-0.88 \\
-1.09\end{array}$ & $\begin{array}{r}(7.74) \\
(-6.64) \\
(-2.00) \\
(0.06) \\
(6.93) \\
(-0.06) \\
(5.46) \\
(-1.50) \\
(-3.51)\end{array}$ \\
\hline $\begin{array}{l}\text { Sales workers } \\
\text { Service workers } \\
\text { Agricultural workers } \\
\text { Production workers }\end{array}$ & & & $\begin{array}{r}-0.01 \\
0.25 \\
-0.51 \\
-0.02\end{array}$ & $\begin{array}{r}(-0.09) \\
(1.21) \\
(-2.21) \\
(-0.78)\end{array}$ \\
\hline $\begin{array}{l}\text { Intermediate skilled } \\
\text { Highly skilled }\end{array}$ & $\begin{array}{l}2.53 \\
1.46\end{array}$ & $\begin{array}{l}(4.84) \\
(5.54)\end{array}$ & $\begin{array}{l}1.8233 \\
2.9325\end{array}$ & $\begin{array}{l}(2.88) \\
(3.13)\end{array}$ \\
\hline
\end{tabular}

Source: ROA

We can conclude that, in any given occupational field, initial education and participation in training are actually complementary: highly skilled workers invest more in on-going training than the intermediately skilled. This means that the recruitment policies and training policies of firms can be seen as complementary rather than substitutable policies. Within the broadly-defined occupational domains, training policies therefore increase the skill gap between the highly skilled and the intermediate skilled workers. Moreover, both intermediate and highly skilled workers participate significantly more in continuing training than low skilled workers. This again indicates an increase of the skill gap in the labour force in the EU Member States. This means that continuing training fails to fails to achieve the upgrading of low skilled workers which is required if the labour supply is to be adjusted to transfer human resources towards activities which match the EU's comparative advantages (cf. Commission of the European Communities, 1993 and ILO, 1995). 


\section{Conclusion}

From the Heckscher-Ohlin theorem, one would expect countries to specialize in products that make use of their most abundant production factors. Porter extended the determinants of national competitive advantages in his diamond-metaphor, in which he included demand conditions, supporting industries and domestic industries into account. However Porter stresses that, as a result of globalization, the knowledge and skills needed to produce have become much more important than factor abundance.

To catch up in the technological race and to increase the long-term flexibility of their labour forces, industrialized countries require an adequately skilled labour force. Because of their relatively high wage levels, the EU Member States require a continuous upgrading of the skill level of the labour force if they are to maintain, or regain, their competitive position relative to the newly industrialized countries. This investment in human capital can take place by means of increased investment in initial education, which enables firms to increase the skill level of their workforce by means of a recruitment policy. Another way of upgrading the skill level of the workforce is via participation in continuing training (a training policy). This training is mostly paid for by the firm and offers the advantage of increasing the available firm-specific human capital.

We began by analyzing human capital investment in initial education. An increase in the number of intermediate and highly skilled workers could be observed in the various Member States of the European Union although there were large differences between the Member States. The developments indicate an increase in the skill level of the labour force. To find out to what extent these upgrading tendencies are due to changes in the occupational structure of employment and to what extent they reflect increases in the skill levels within the various occupational sectors, a shift-share analysis was performed. This shift-share analysis showed that the substitution effect, i.e. the increase of the skill level within occupational sectors, is the main cause for the increasing skill level of the working population in the European Union. However in the three Southern Member States of the European Union - Portugal, Spain and Greece - the upgrading of the labour force was caused by shifts in the industrial and occupational structure of employment.

To find out whether there are converging or diverging trends between the various EU Member States with regard to human capital investments in initial education and continuing vocational training, a convergence/divergence analysis was performed. The results of this analysis showed a slight diverging trend, indicating an increasing skill gap, in several occupational fields, between the Member States. The divergence/convergence analysis also showed that the skill level differences between the European Union Member States are largest for the occupational sectors which have the highest employment shares for intermediate and highly skilled workers. This indicates that the competitive positions of the Member States of the European Union may change considerably in the coming years. In 
Porters' terminology, this could even mean that knowledge centres and production centres could arise within the European Union.

With respect to participation in continuing vocational training, we found that the United Kingdom, the Netherlands and Denmark show particularly high participation rates. The divergence/convergence analysis with respect to continuing vocational training showed a divergence in most occupational sectors. One exception was the sector of clerical workers, with a slightly converging trend which is probably due to the training courses required to work with text and data processing information technology. The differences in training participation between the Member States were much bigger than the differences between the educational levels of the labour forces in the various Member States.

Finally, we analyzed whether initial training (recruitment policies) and continuing training are substitutes or complements. Estimation results show that intermediate skilled workers generally participate more in training activities than highly skilled workers. This indicates the substitutability of initial education and continuing training. However a second analysis, controlled for the occupational field in which workers are employed, showed that highly skilled workers participate more in training than intermediate skilled workers. The results from this analysis indicate that, for a given occupational field, recruitment policies and training policies are complementary rather than substitutes, which means that within the various occupational fields, continuing training policies increase the skill gap between the intermediate skilled and highly skilled workers. Moreover, both intermediate and highly skilled workers participate significantly more in continuing training than low skilled workers, whether or not a correction is made for the occupational field in which they are employed. This again indicates an increase in the skill gap in the labour force in the EU Member States. The implication is that investments in continuing training fail to achieve the upgrading of low skilled workers which is required if the labour supply is to be adjusted to transfer human resources towards activities which match the EU's comparative advantages.

\section{References}

Amemiya, T., F. Nold (1975), A Modified Logit Model, Review of Economics and Statistics, vol. 57, pp. 255-257.

Bartel, A.P., F.R. Lichtenberg (1987), The comparative advantage of educated workers in implementing new technology, The Review of Economics and Statistics, vol. 69, 1987, pp. 1-11.

Becker, G.S. (1964), Human capital: A theoretical and empirical analysis, with special reference to education, NBER, New York.

Braverman, H. (1974), Labor and Monopoly Capital: The Degradation of Work in the Twentieth Century, Monthly Review Press, New York/London.

Chacholiades, M. (1978), International trade theory and policy, McGraw-Hill, London. 
Commission of the European Communities (1993), Growth, Competitiveness, Employment: the Challenges and ways forward to the 21st Century, Bulletin of the European Communities. Supplement 6/1993. Office for Official Publications of the European Communities, Luxembourg.

Cörvers, F., A. de Grip (1995), Explaining trade in industrialized countries by countryspecific human capital factor endowments, ROA-RM-1995/3E, Maastricht.

Daly, A. (1986), Education and Productivity, A comparison of Great Britain and the United States, British Journal of Industrial Relations, vol. 24, pp. 251-266.

Delsen, L. (1995), Atypical Employment: an International Perspective. Causes, Consequences and Policy, Wolter-Noordhoff, Groningen.

Dosi, G., K. Pavitt, L. Soete (1990), The economics of technical change and international trade, Harvester Wheatsheaf, New York.

Ethier, J.E. (1988), Modern International Economics, W.W. Norton and Company, London.

Grip, A. de, J. Hoevenberg, E. Willems, Atypical Employment Relations by Occupational sector in the European Union, ROA-RM-1995/5E, Maastricht.

Groot, W. (1991), Overeducation and the returns to enterprise-related schooling, Economics of Education Review, vol. 12, pp. 299-309.

Groot, L.F.M., A. de Grip (1991), Technological change and skill formation in the bank sector, Economics of Education Review, vol. 10, pp. 57-71.

Hoevenberg, J., A. de Grip (1994), Indicators of occupational employment in the European Union, ROA-R-1994/3E, Maastricht.

ILO (1995), World Employment 1995. An ILO Report, Internation Labour Organization, Geneva.

Judge, G.G., W.E. Griffiths, R. Carter Hill, T.-S. Lee, The Theory and Practice of Econometrics, John Wiley and Sons, New York, 1980.

Leamer, E.E. (1984), Sources of International Comparative Advantage, Theory and Evidence, MIT Press, Cambridge, Massachusetts.

Leamer, E.E. (1992), Testing Trade Theory, NBER, Working Paper no. 3957, New York.

Leontief, W.W. (1953), Domestic production and foreign trade; the American position reexamined, Proceedings of the American Philosophical Society, vol. 97, pp. 332-349.

OECD (1995), The OECD Jobs Study. Evidence and Explanations, Part II; The Adjustment Potential of the Labour Market, OECD, Paris.

Porter, M. (1990), The Competitive Advantage of Nations, Macmillan Press, London.

Ryan, P. (1991), International comparisons of vocational education and training for intermediate skills, The Falmer Press, New York.

Rumberger, R.W., H.M. Levin (1989), Schooling for the modern workplace, in: Investing in People: A Strategy for addressing America's Workforce Crisis: Background Paper, Commission on Workforce Quality and Labor Market Efficiency, U.S. Department of Labor, Washington D.C., vol. 1, pp. 85-114.

Schultz, T.W. (1971), Investment in human capital: The role of education and of research, Free Press, New York.

Spenner, K.I. (1985), The upgrading and downgrading of occupations: Issues, evidence and implications for education, Review of Educational Research, vol. 55, pp. 125-154.

Teulings, C. and M. Koopmanschap (1989), An econometric model of crowding out of lower educational levels, European Economic Review, vol. 33, pp. 1653-1664. 
Treu, T. (1992), Labour flexibility in Europe, International Labour Review, vol. 131, pp. 497512.

U.S. Department of Labor, Commission on Workforce Quality and Labor Market Efficiency (1989), Investing in People: A Strategy for Addressing America's Workforce Crisis, United States Printing Office, Washington D.C. 


\section{Appendix A The (modified) binomial logit model}

Let $p_{i j}$ be the probability that workers in country $i(i=1 . . l)$ and occupation $j(j=1 . . J)$ obtain training. We will try to explain this probability by means of country effects, occupation effects and the educational structure of the labour force by country and occupation.

The model can then be specified as follows (cf. Amemiya and Nold, 1975):

$p_{i j}=\frac{\exp \left[\beta_{0}+\beta_{i}+\beta_{j}+\sum_{k} \beta_{k} x_{k i j}+v_{i j}\right]}{1+\exp \left[\beta_{0}+\beta_{i}+\beta_{j}+\sum_{k} \beta_{k} x_{k i j}+v_{i j}\right]}$

in which:

$\beta_{0}, \beta_{i}, \beta_{j}, \beta_{k} \quad=$ parameters;

$x_{k i j} \quad=$ k explanatory variables;

$v_{i j} \quad=$ specification error term.

Now define (see also Judge et al., 1980, pp. 325-331):

$\beta_{i}^{*}=\beta_{i}-\beta_{l}$

$\beta_{j}^{*}=\beta_{j}-\beta_{J}$

where $I$ is the reference country and $J$ is the reference occupation.

Then equation (A.1) can be rewritten as:

$p_{i j}=\frac{\exp \left[X \beta+v_{i j}\right]}{1+\exp \left[X \beta+v_{i j}\right]}$

with:

$X=\left(j_{I J}\left(\begin{array}{l}I_{l-1} \\ O^{\prime}\end{array}\right) \otimes j_{J} j_{I}\left(\begin{array}{l}I_{j-1} \\ O^{\prime}\end{array}\right) X 3\right)$ 
and:

$\beta=\left(\begin{array}{l}\beta_{0} \\ \beta_{1}^{*} \\ \beta_{2}^{*} \\ \beta_{3}\end{array}\right)$

where:

$\beta_{1}^{*} \quad=$ vector of parameters $\beta_{i}^{*}(i=1 . . l-1)$

$\beta_{2}^{*} \quad=$ vector of parameters $\beta_{j}^{*}(j=1 . . J-1)$;

$\beta_{3} \quad=$ vector of parameters $\beta_{k}$

$j_{K} \quad=\mathrm{K} \times 1$ vector of ones;

$I_{K} \quad=\mathrm{K} \times \mathrm{K}$ identity matrix;

$\otimes \quad=$ Kronecker's product.

However, the probability $p_{i j}$ cannot be observed. What we do observe is the fraction $f_{i j}$ :

$f_{i j}=\frac{\text { observed number of workers receiving training } 0 \text { country } i \text { occupation } j}{\text { observed total number of workers } 0 \text { country } i \text { occupation } j}$

This introduces an additional measurement error in the model. According to Amemiya and Nold (1975) this modified logit model can be estimated as follows.

Let:

$f_{i j}^{\prime}=X \beta+v_{i j}+u_{i j}$

in which:

$f_{i j}^{\prime}=\log \left(\frac{f_{i j}}{1-f_{i j}}\right)$

The model can be estimated by means of a two-stage procedure:

First, the OLS-estimator $\hat{\beta}_{1}$ of equation (A.3) is calculated:

$\hat{\beta}=\left(X^{\prime} X\right)^{-1} X^{\prime} f^{\prime}$ 
then define: $:^{11}$

$$
s^{2}=\frac{1}{N-K}\left[\sum_{i j}\left(f_{i j}^{\prime}-x_{i j} \hat{\beta}\right)^{2}-\sum_{i j} \frac{1}{n_{i j} f_{i j}\left(1-f_{i j}\right)}\right]
$$

in which:

$N \quad=$ number of observations;

$K=$ number of parameters;

$n_{i j}=$ observed number of workers in country $i$ and occupation $j$.

and:

$f_{i j}^{*}=\left[\frac{1}{\sqrt{s^{2}+\frac{1}{n_{i j} p_{i j}\left(1-p_{i j}\right)}}}\right] f_{i j}^{\prime}$

$x_{i j}^{*}=\left[\frac{1}{\sqrt{s^{2}+\frac{1}{n_{i j} p_{i j}\left(1-p_{i j}\right)}}}\right] x_{i j}$

The estimator $\hat{\beta}$ for $\beta$ is then:

$\hat{\beta}=\left(X^{*^{\prime}} X^{*}\right)^{-1} X^{*^{\prime}} f^{*}$

The variance-covariance matrix of $\hat{\beta}$ is:

$\hat{\Sigma_{\beta}}=\left(X^{*} X^{*}\right)^{-1}$

11. Amemiya and Nold use $\mathrm{N}$ instead of $\mathrm{N}-\mathrm{K}$ in this formula. 